Document downloaded from:

http://hdl.handle.net/10251/153234

This paper must be cited as:

Espinosa, M.; Blay, G.; Cardona, L.; Muñoz Roca, MDC.; Pedro, JR. (2017). Catalytic Asymmetric Formal [3+2] Cycloaddition of 2-Isocyanatomalonate Esters and Unsaturated Imines: Synthesis of Highly Substituted Chiral g-Lactams. Chemistry - A European Journal. 23(59):14707-14711. https://doi.org/10.1002/chem.201702777

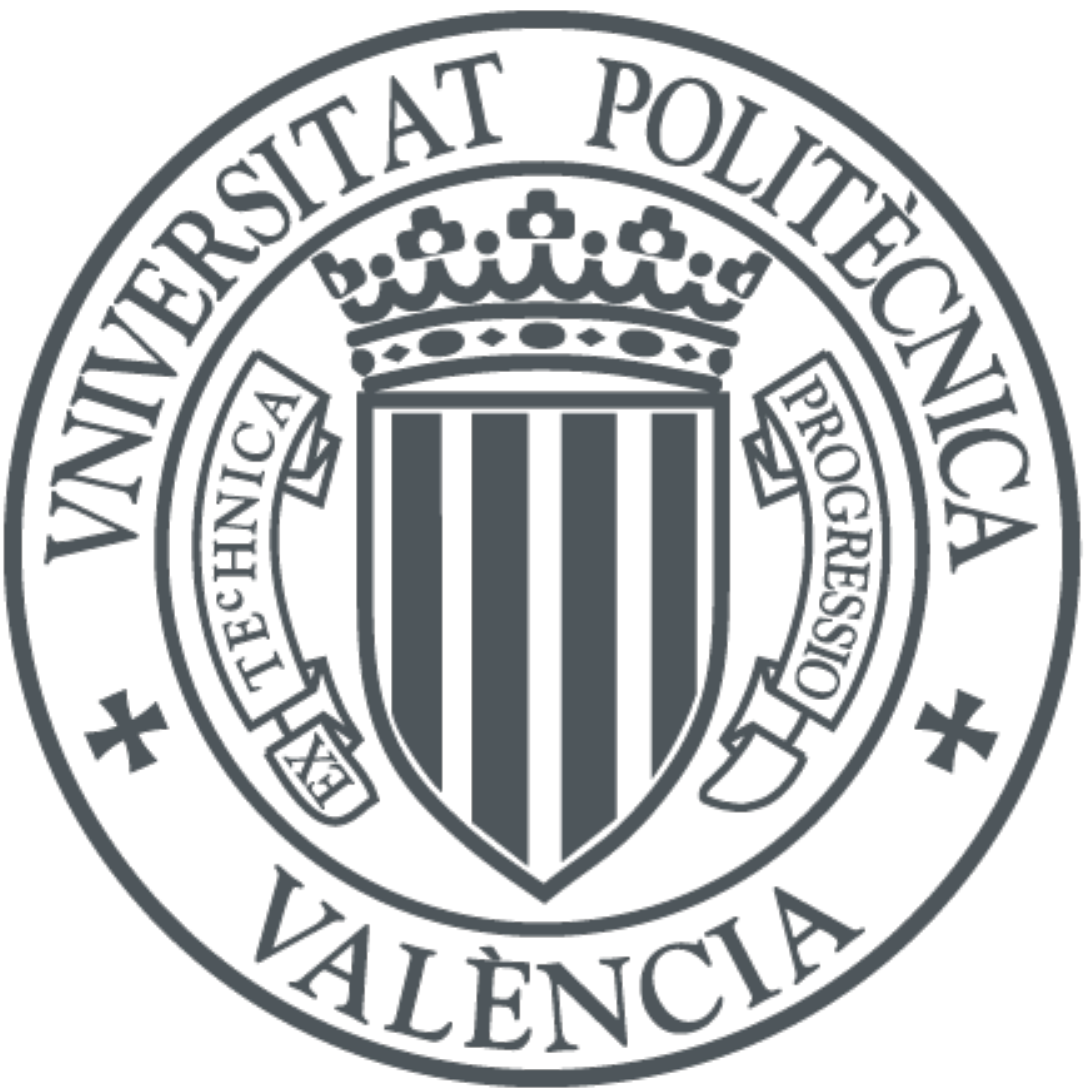

The final publication is available at

https://doi.org/10.1002/chem.201702777

Copyright John Wiley \& Sons

Additional Information 


\title{
Catalytic Asymmetric Formal [3+2] Cycloaddition of 2-Isocyanatomalonate Esters and Unsaturated Imines: Synthesis of Highly Substituted Chiral g-Lactams
}

\author{
Miguel Espinosa, ${ }^{[a]}$ Gonzalo Blay, ${ }^{*[a]}$ Luz Cardona,${ }^{[a]}$ M. Carmen MuÇoz, ${ }^{[b]}$ and Jos8 R. Pedro ${ }^{*[a]}$
}

Abstract: Unlike their isocyano and isothiocyanato analogues, isocyanato esters remain almost unexplored as formal 1,3-dipoles in asymmetric catalytic reactions. The first asymmetric formal [3+2] cycloaddition involving isocyanato esters and electrophilic alkenes is reported. Diisopropyl 2-isocyanatomalonate reacts with a,b-unsaturated $\mathrm{N}$-(o-anisidyl) imines in the presence of a $\mathrm{Mg}(\mathrm{OTf})_{2}-\mathrm{BOX}$ complex to give highly substituted chiral pyrrolidinones featuring a conjugate exocyclic double bond with excellent yields and enantiomeric excesses up to $99 \%$. Several transformations of the resulting heterocycles, including the synthesis of a pyroglutamic acid derivative, have been carried out.

Pyrrolidinones (g-lactams) and, in particular, 2-alkoxycarbonylpyrrolidinones (pyroglutamic acid derivatives) have been extensively used as building blocks in synthetic chemistry ${ }^{[1]}$ and as chiral ligands in asymmetric catalysis. ${ }^{[2]}$ They are also structural units frequently encountered in numerous biologically active natural products and pharmaceuticals (Figure 1). Examples include the marine metabolite (@)salinosporamide A, currently tested as an anticancer drug candidate,,$^{[3]}$ the proteasome inhibitors antiprotealide and lactacystin, ${ }^{[4]}$ the antibiotic and antitumoral compound neooxazolmycin, isolated form a strain of Streptomyces, ${ }^{[5]}$ the neuroexcitotoxic dysibetaine, isolated from the Micronesian sponge Dysidea herbacea, ${ }^{[6]}$ or the lipooligosaccharides found in the cell wall of different myco-

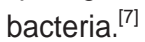

Given the widespread chemical significance of these scaffolds, the development of new efficient and atom-economic processes for the construction of these heterocyclic systems, especially in an enantioselective manner, constitutes an impor-

[a] M. Espinosa, Prof. Dr. G. Blay, Prof. Dr. L. Cardona, Prof. Dr. J. R. Pedro

Departament de Qułmica Org/nica, Facultat de Qułmica

Universitat de ValHncia, C/ Dr. Moliner 50, 46100 Burjassot (Spain)

E-mail: gonzalo.blay@uv.es jose.r.pedro@uv.es

[b] Prof. Dr. M. C. Muçoz

Departament de Fisica Aplicada, Universitat PolitHcnica de ValHncia Caml de Vera, S/N, 46071 ValHncia (Spain)

므 Supporting information and the ORCID identification number(s) for the au-

(iD) thor(s) of this article can be found under https://doi.org/10.1002/ chem. 201702777
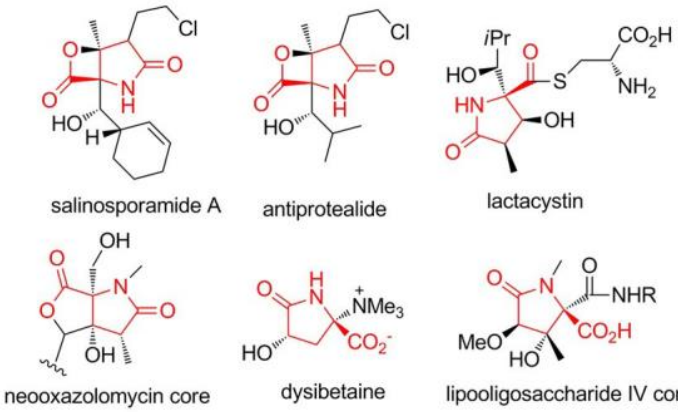

$$
\text { neooxazolomycin core }
$$
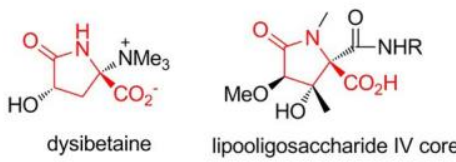

Figure 1. Examples of bioactive natural compounds incorporating a pyrrolidinone unit.

tant challenge in current organic synthesis. Besides procedures based on the structural modification of nitrogen-containing heterocycles, such as pyrrolidinones, pyroglutamic acid, or succinimides ${ }^{[8]}$ cyclization procedures in which the pyrrolidinone heterocycle is formed from acyclic precursors result especially appealing. The Michael addition/lactamization reaction of 2 amino acids and unsaturated acid derivatives is one of the first used procedures for the synthesis of g-lactams. ${ }^{[9]}$ Recently, the double Michael addition of amide-tethered diacids with alkynones ${ }^{[10]}$ and the Conia-ene reaction of alkynyl amidomalonates ${ }^{[11]}$ have been used in the synthesis of pyroglutamic acid derivatives. However, most of the methods for the enantioselective synthesis of pyrrolidinones are still based on chiral starting materials or stoichiometric reagents, ${ }^{[12]}$ and only few asymmetric catalytic procedures are available. Among them, enantioselective versions of the Michael addition/lactamization reaction of 2-amino acids and unsaturated acid derivatives have been reported by several groups. ${ }^{[13]}$ Chiral g-lactams have been obtained with excellent enantioselectivities through N-heterocyclic carbene-catalyzed coupling of imines with unsaturated aldehydes. ${ }^{[14]}$ Finally, the reaction between 2-aminomalonates and Morita-Baylis-Hillman carbonates catalyzed by chiral Lewis bases to give a-methylene-g-lactams with moderate enantioselectivity has been recently reported. ${ }^{[15]}$

On the other hand, 2-isocyano ${ }^{[16]}$ and 2-isothiocyanato ${ }^{[17]}$ esters have been increasingly used as formal 1,3-dipoles in asymmetric synthesis over the last years. These compounds react with different unsaturated groups to give a variety of five-membered nitrogen-containing heterocycles. In particular, their participation in asymmetric catalytic formal [3+2] cycloaddition reactions with conjugate carbonyl compounds has 
Communication 


$$
\begin{aligned}
& \text { a) Enantioselective [3+2] cycloaddition reaction with } \\
& \text { 2-isocyano- and 2-isothiocyanato esters. Many examples. } \\
& \mathrm{RO}_{2} \mathrm{C} \smile \mathrm{NCO}+\mathrm{R}^{1} \text { EWG } \stackrel{\text { paper }}{\longrightarrow} \text { this } \\
& \text { 2-isocyanato esters. Unprecedented. }
\end{aligned}
$$

Scheme 1. Formal [3+2] cycloadditions.

provided a straightforward access to enantiomerically enriched pyrrolidines ${ }^{[18]}$ or thiopyrrolidinones, ${ }^{[19]}$ respectively (Scheme 1). Following these antecedents, we envisaged that a formal [3+2] cycloaddition between a 2-isocyanato esters and a proper Michael acceptor may be used for the efficient and atom-economic enantioselective synthesis of 2-alkoxycarbonylpyrrolidinones (Scheme 1). However, the use of 2-isocyanato esters in reactions that combine both nucleophilic and electrophilic behavior (1,3-dipole-like behavior) is challenging due to the higher reactivity of the isocyanate group compared to the isocyano and isothiocyanate groups. In fact, 2-isocyanato esters have been mainly used as electrophiles for the preparation of ureas and carbamates, ${ }^{[20]}$ whereas reactions making use of their 1,3-dipole-like character are almost unknown. To the best of our knowledge, the organocatalytic reaction of 2-isocyanatomalonate esters and aldehydes to give oxazolidinones developed by Takemoto et al. ${ }^{[21]}$ is the only example reported in the literature so far. ${ }^{[22]}$ Following our research on the use of 1-aza-butadienes as electrophiles, ${ }^{[23]}$ we report here the first example of enantioselective formal [3+2] cycloaddition reactions of 2-isocyanato esters with alkenes to give highly substituted a,b-unsaturated g-lactams. The reaction is carried out by using unsaturated imines, 2-isocyanatomalonate esters, and a MgBOX complex as catalyst (Scheme 2).

We initially investigated the activity of the La"I-pyBOX1, Ca"pyBOX1, and Mg"-BOX1 complexes in the reaction between diethyl 2-isocyanatomalonate (1) and the imine 4 a derived from o-anisidine (Table 1, entries $1-3) \cdot{ }^{[24]}$ In all cases, the reaction proceeded smoothly to give the pyrrolidinone $5 \mathrm{a}$, which features a conjugated exocyclic double bond, a structural moiety that is present in a large number of antitumor compounds. Compound $5 \mathrm{a}$ was obtained as a single geometric isomer having the $Z$ configuration at the double bond. Regarding the enantioselectivity, the La"I-pyBOX1 complex gave compound $5 \mathrm{a}$ in almost racemic form, whereas the Ca"-pyBOX1 and Mg"BOX1 complexes showed similar enantioselectivities (ee $=67 \%$, ee =enantiomeric excess), although the magnesium complex seemed slightly more active. Further research was continued by testing several Mg-BOX complexes. The best result was obtained with BOX6 that provided compound $5 \mathrm{a}$ in $97 \%$ yield with $71 \%$ ee (Table 1 , entry 8 ). A decrease of the temperature

\begin{tabular}{|c|c|c|c|c|c|c|c|c|}
\hline Entry & $M$ & $\mathrm{~L}$ & Solvent & $\mathrm{R}$ & $\mathrm{T}[8 \mathrm{C}]$ & $\mathrm{t}[\mathrm{h}]$ & Yield [\%] $]^{[b]}$ & ee $[\%]^{[c]}$ \\
\hline 1 & $\mathrm{La}(\mathrm{OTf})_{3}$ & pyBOX1 & $\mathrm{CH}_{2} \mathrm{Cl}_{2}$ & Et & 25 & 3 & 81 & 3 \\
\hline 2 & $\mathrm{Ca}(\mathrm{OTf})_{2}$ & pyBOX1 & $\mathrm{CH}_{2} \mathrm{Cl}_{2}$ & Et & 25 & 3.5 & 89 & @67 \\
\hline 3 & $\mathrm{Mg}(\mathrm{OTf})_{2}$ & BOX1 & $\mathrm{CH}_{2} \mathrm{Cl}_{2}$ & Et & 25 & 2 & 97 & @67 \\
\hline 4 & $\mathrm{Mg}(\mathrm{OTf})_{2}$ & BOX2 & $\mathrm{CH}_{2} \mathrm{Cl}_{2}$ & Et & 25 & 2.5 & 83 & $@ 5$ \\
\hline 5 & $\mathrm{Mg}(\mathrm{OTf})_{2}$ & BOX3 & $\mathrm{CH}_{2} \mathrm{Cl}_{2}$ & Et & 25 & 2.5 & 89 & @5 \\
\hline 6 & $\mathrm{Mg}(\mathrm{OTf})_{2}$ & BOX4 & $\mathrm{CH}_{2} \mathrm{Cl}_{2}$ & Et & 25 & 3 & 94 & 63 \\
\hline 7 & $\mathrm{Mg}(\mathrm{OTf})_{2}$ & BOX5 & $\mathrm{CH}_{2} \mathrm{Cl}_{2}$ & Et & 25 & 3 & 97 & 29 \\
\hline 8 & $\mathrm{Mg}(\mathrm{OTf})_{2}$ & BOX6 & $\mathrm{CH}_{2} \mathrm{Cl}_{2}$ & Et & 25 & 2.5 & 97 & 71 \\
\hline 9 & $\mathrm{Mg}(\mathrm{OTf})_{2}$ & BOX6 & $\mathrm{CH}_{2} \mathrm{Cl}_{2}$ & Et & 0 & 3 & 96 & 80 \\
\hline 10 & $\mathrm{Mg}(\mathrm{OTf})_{2}$ & BOX6 & $\mathrm{CH}_{2} \mathrm{Cl}_{2}$ & Et & $@ 20$ & 45 & 68 & 43 \\
\hline 11 & $\mathrm{Mg}(\mathrm{OTf})_{2}$ & BOX6 & $\mathrm{CH}_{2} \mathrm{Cl}_{2}$ & $\mathrm{Me}$ & 0 & 2 & 98 & 49 \\
\hline 12 & $\mathrm{Mg}(\mathrm{OTf})_{2}$ & BOX6 & $\mathrm{CH}_{2} \mathrm{Cl}_{2}$ & $\mathrm{iPr}$ & 0 & 2 & 98 & 89 \\
\hline 13 & $\mathrm{Mg}(\mathrm{OTf})_{2}$ & BOX6 & $\left(\mathrm{ClCH}_{2}\right)_{2}$ & iPr & 0 & 2.5 & 98 & 76 \\
\hline 14 & $\operatorname{Mg}(\mathrm{OTf})_{2}$ & BOX6 & $\mathrm{CHCl}_{3}$ & $\mathrm{iPr}$ & 0 & 2.5 & 89 & 91 \\
\hline 15 & $\mathrm{Mg}(\mathrm{OTf})_{2}$ & BOX6 & $\mathrm{Et}_{2} \mathrm{O}$ & $\mathrm{iPr}$ & 0 & 2.5 & 96 & 91 \\
\hline 16 & $\mathrm{Mg}(\mathrm{OTf})_{2}$ & BOX7 & $\mathrm{Et}_{2} \mathrm{O}$ & $\mathrm{iPr}$ & 0 & 1.5 & 97 & 97 \\
\hline
\end{tabular}

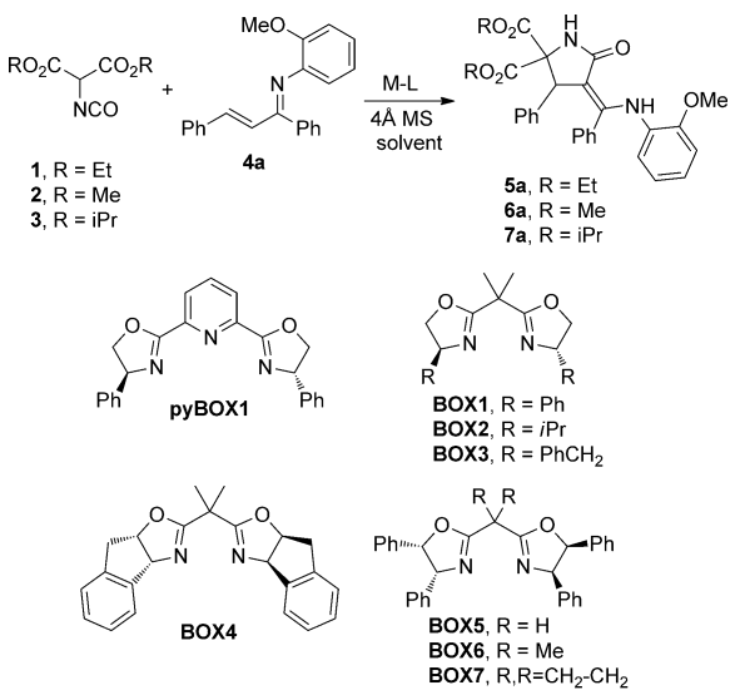

Scheme 2. Formal [3+2] cycloaddition between 2-isocyanatomalonates and unsaturated imines, and ligands used in this study.

Table 1. Enantioselective [3+2] cycloaddition of isocyanatomalonate esters with the unsaturated imine $4 \mathrm{a}$. Optimization of the reaction conditions.[a]

[a] Reaction conditions: compounds 1-3 (0.19 mmol), compound $4 \mathrm{a}$ (0.125 mmol, $\mathrm{C}=\mathrm{N}$ geometry isomer mixture), $\mathrm{L}\left(0.0125 \mathrm{mmol}, \mathrm{M}(\mathrm{OTf})_{2}\right.$ $(0.0125 \mathrm{mmol}), 4 \mathrm{a} \mathrm{MS}(110 \mathrm{mg})$, solvent $(1.1 \mathrm{~mL})$. [b] Yield of the isolated product. [c] Determined by HPLC with chiral stationary phases; opposite signs indicate opposite enantiomers.

to $08 \mathrm{C}$ increased the ee up to $80 \%$, however, a further decrease of the temperature to @208C produced a dramatic drop of the enantioselectivity (Table 1, entries 9 and 10). With the optimal temperature $(08 \mathrm{C})$, the effect of the alkoxy group in the 2-isocyanatomalonate ester was tested (Table 1, entries 9, 11 , and 12).

It was found that the diisopropyl ester 3 underwent a more enantioselective reaction than diethyl or dimethyl 2-isocyanatomalonates, giving lactam $7 \mathrm{a}$ in $98 \%$ yield with $89 \%$ ee. Next, the effect of the solvent was checked. The use of diethyl ether as the solvent in the addition of compound 3 to compound $4 \mathrm{a}$ allowed increasing the ee of compound $7 \mathrm{a}$ up to $91 \%$ 
(Table 1, entry 15). Finally, in view of the important effect of the substitution at the central carbon atom of the BOX ligand on the enantioselectivity of the reaction (Table 1, entry 7 vs. entry 8), the cyclopropylic BOX7 ligand was prepared and tested providing compound $7 \mathrm{a}$ in excellent $97 \%$ yield and $97 \%$ ee (Table 1 , entry 16 ).

With the best conditions available the scope of the reaction of diisopropyl 2-isocyanatomalonate (3) and the a,b-unsaturated $\mathrm{N}$-(o-methoxyphenyl)imines $4^{[25]}$ by using the $\mathrm{Mg}(\mathrm{OTf})_{2}-$ BOX7 ( $\mathrm{Tf}=$ triflate) complex as catalyst was studied. The results are gathered in Table 2 . The reaction can be carried out with

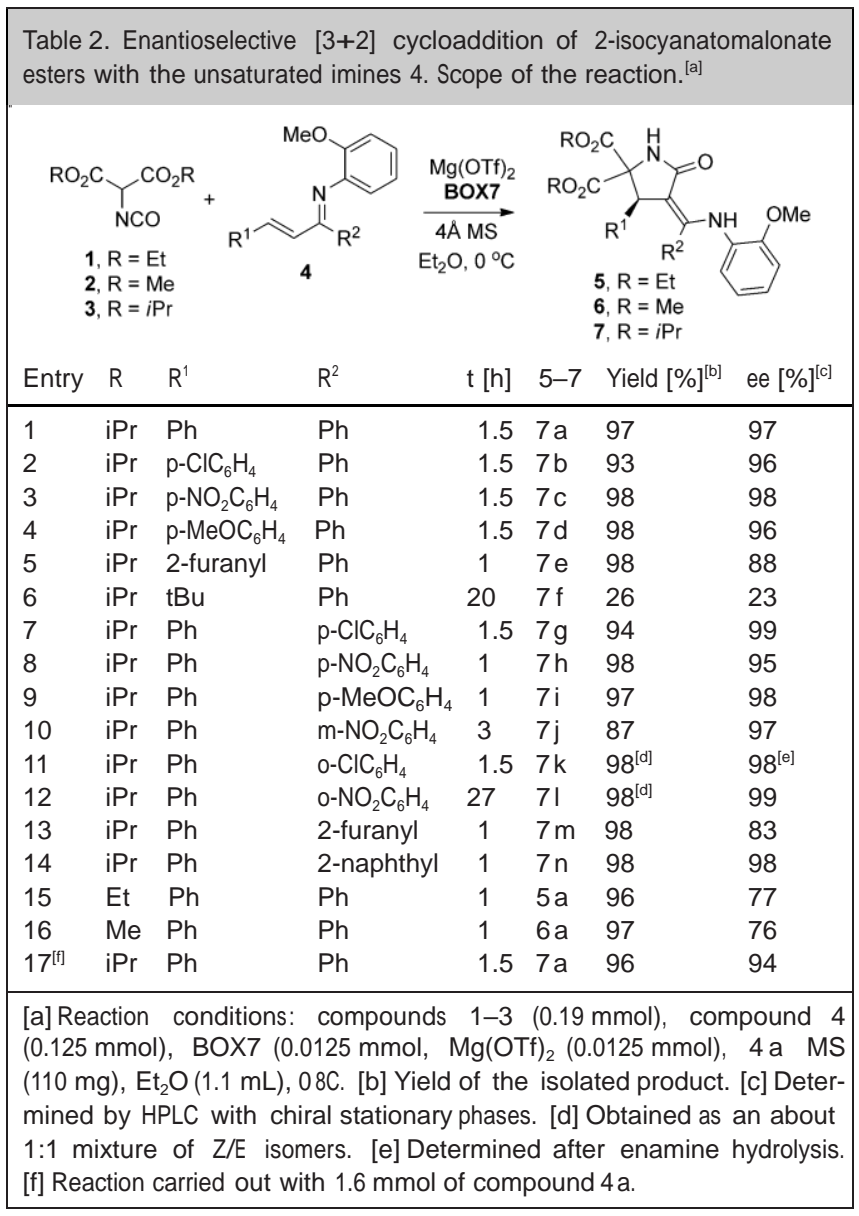

imines bearing at the b-carbon atom an aromatic ring substituted with either electron-withdrawing (Table 2, entries 2 and 3 ) or electron-donating groups (Table 2, entry 4), to give the expected products $7 b-7 d$ with excellent yields and enantioselectivities. The residue $R^{1}$ can also be a heterocyclic furanyl ring (Table 2, entry 5). In this case, compound 7 e was obtained in almost quantitative yield and slightly lower ee $(88 \%)$. The introduction of a bulky tert-butyl group at the b-carbon atom brought about a decrease of the reaction rate and the expected lactam $7 \mathrm{f}$ was obtained with low yield and enantioselectivity (Table 2, entry 6).

The $\mathrm{R}^{2}$ group attached to the azomethinic carbon atom was also amenable to variation (Table 2, entries 7-14). Aromatic rings bearing either electron-withdrawing or electron-donating groups were permitted without showing much influence on the enantioselectivity of the reaction. Again, when $\mathrm{R}^{2}$ was a 2furanyl group, compound $7 \mathrm{~m}$ was obtained with lower ee, although with high yield (Table 2, entry 13). A naphthyl group attached to the imine was also tolerated, compound $7 \mathrm{n}$ being obtained in $98 \%$ yield and $98 \%$ ee (Table 2 , entry 14). As anticipated, diethyl and dimethyl 2-isocyanatomalonates reacted with compound $4 \mathrm{a}$ to give the expected lactams with lower enantioselectivity than diisopropyl 2-isocyanatomalonate (Table 2, entries 15 and 16). To further demonstrate the practicality of this newly developed procedure, the reaction of compounds 3 and $4 \mathrm{a}$ was carried out on a $1.6 \mathrm{mmol}$ scale (500 mg). Product 7 a was obtained in $96 \%$ yield with minimal erosion in the enantioselectivity ( $94 \%$ ee, Table 2 , entry 17$)$.

In all the examples studied except with the imines $4 \mathrm{k}$ and $4 \mathrm{I}$, which have an o-substituted phenyl ring attached to the azomethinic carbon atom, compounds 5-7 were obtained as a single diastereomer. Compound $7 \mathrm{~b}$ (Table 2, entry 2 ) could be crystallized and subjected to X-ray analysis, ${ }^{[26]}$ what allowed to establish the geometry of the enamine double bond as $Z$ and the configuration of the stereogenic center as $R$ (Figure 2). The absolute stereochemistry of all compounds 5-7 was assigned by analogy upon the assumption of a uniform stereochemical pathway.

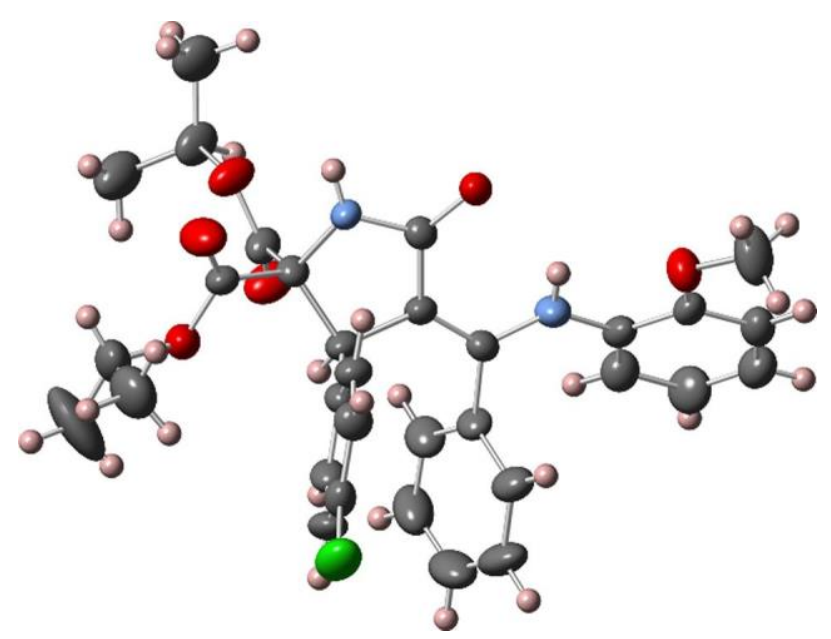

Figure 2. ORTEP plot for the X-ray structure of compound $7 \mathrm{~b}$. The thermal ellipsoids are drawn at the $50 \%$ probability level. Flack parameter $=@ 0.16(8)$.

Some transformations were carried out on compound 7 a (Scheme 3). Thus, aqueous hydrolysis of the enamine with concentrated $\mathrm{HCl}$ in THF gave ketone $8 \mathrm{a}$ in $90 \%$ yield. On the other hand, treatment of compound $3 \mathrm{a}$ with $\mathrm{NaBH}_{3} \mathrm{CN}-\mathrm{AcOH}$ $(\mathrm{Ac}=\mathrm{acyl})$ in $\mathrm{EtOH}$ provided the major amine $9 \mathrm{a}^{[26]}$ in $75 \%$ yield, together with an isomeric amine $9 \mathrm{a}$ ", whose stereochemistry could not be assigned, in $11 \%$ yield. Also, the chemoselective transesterification of the diisopropyl ester $7 \mathrm{a}$ to give the mixed diester 10 a was efficiently achieved in $89 \%$ yield by treatment with $\mathrm{NaOMe} / \mathrm{MeOH}$. Finally, the pyroglutamic acid derivative 11 a was obtained in $87 \%$ yield after hydrolysis/decarboxylation upon treatment of compound $7 \mathrm{a}$ 


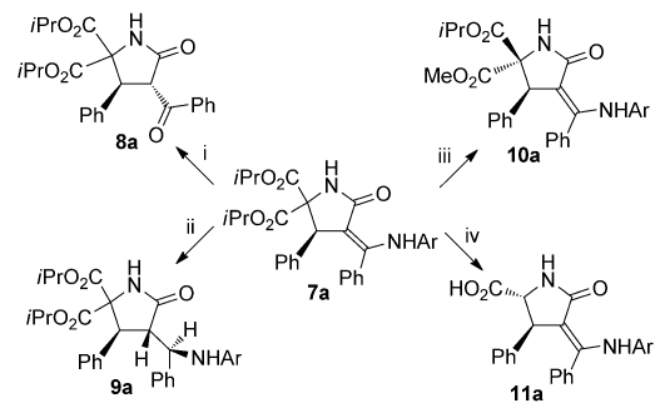

Scheme 3. $\mathrm{Ar}=0-\mathrm{MeOC}_{6} \mathrm{H}_{4}$. i) $\mathrm{HCl}$, THF, RT, yielding product $8 \mathrm{a}$ in $90 \%$. ii) $\mathrm{NaBH}_{3} \mathrm{CN}, \mathrm{AcOH}, \mathrm{EtOH}, 08 \mathrm{C}$, yielding product $9 \mathrm{a}$ in 75 and product 9 a" (i.e., a diastereomer of compound $9 \mathrm{a}$ ) in $11 \%$. iii) $\mathrm{NaOMe} / \mathrm{MeOH}, 658 \mathrm{C}$ yielding compound $10 \mathrm{a}$ in $89 \%$. iv) $\mathrm{Et}_{4} \mathrm{NOH}$, DMSO, $808 \mathrm{C}$, yielding compound $11 \mathrm{a}$ in $87 \%$.

with an excess of tetraethylammonium hydroxide in DMSO at $808 \mathrm{C}$. All these reactions took place without a noticeable loss of enantiomeric excess with respect to the starting compound $7 \mathrm{a}$.

A simplified mechanistic proposal for the [3+2] cycloaddition is outlined in Scheme 4. Thus, initial coordination of both reaction partners to the $\mathrm{Mg}^{\mathrm{I}}-\mathrm{BOX}$ complex would bring about a nucleophilic activation of the malonate ester through enolization together with electrophilic activation of the imine (intermediate I). Conjugate addition would lead to the enamine intermediate II, which would undergo nucleophilic addition to the isocyanate group giving the lactam III. Finally, imine/enamine tautomerization and decoordination would give the final products and release the catalyst.

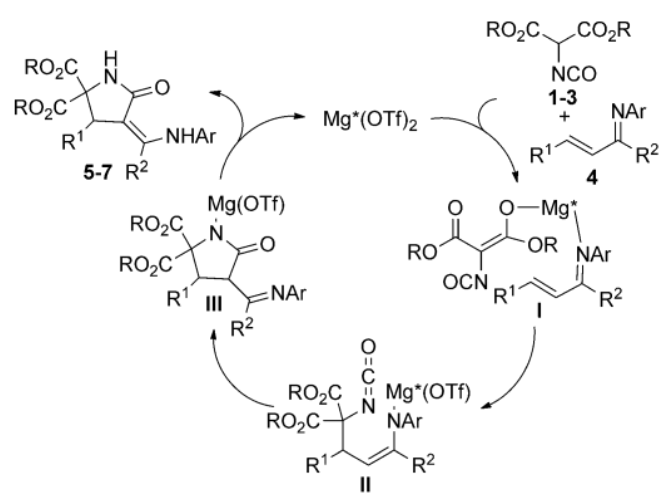

Scheme 4. Simplified mechanistic proposal for the [3+2] cycloaddition. $\mathrm{Mg}^{*}=\mathrm{Mg}-\mathrm{BOX}$.

In summary, we have reported the first enantioselective formal [3+2] cycloaddition of 2-isocyanatomalonate esters with electrophilic alkenes. By using a $\mathrm{Mg}(\mathrm{OTf})_{2}-\mathrm{BOX}$ complex as catalyst, diisopropyl isocyanatomalonate reacted with a,bunsaturated $\mathrm{N}$-(o-anisidyl) imines to give highly substituted chiral pyrrolidinones featuring a conjugate exocyclic double bond. The reaction products, which are derivatives of pyroglutamic acid, were obtained with excellent yields and high to excellent enantioselectivities for a significant number of unsaturated imines. The use of the $\mathrm{N}$-(o-anisidyl) group was essential for the success of the reaction as neither the unsaturated ketone nor the unsaturated $\mathrm{N}$-tosyl imine were reactive with this catalyst. Furthermore, the reaction does not require the use of diastereomerically pure imines, instead mixtures of $\mathrm{C}=\mathrm{N}$ geometric isomers can be used. The application of non-expensive and non-toxic Mg" salts as Lewis acids is another advantage of this procedure. We believe that this reaction will open new possibilities for the potential application of isocyanato esters as formal 1,3-dipoles in asymmetric catalytic reactions. Research toward this goal is currently under progress in our laboratory

\section{Experimental Section}

General procedure for the formal [3+2] reaction: $\mathrm{Mg}(\mathrm{OTf})_{2}$ (4.0 mg, $0.0125 \mathrm{mmol}$ ) was dried in a Schlenk tube under vacuum. BOX7 (6.1 mg, $0.0125 \mathrm{mmol}$ ) was introduced and the Schlenk tube was filled with nitrogen. $\mathrm{Et}_{2} \mathrm{O}(0.55 \mathrm{~mL})$ was added through a syringe and the mixture was stirred for $30 \mathrm{~min}$. The tube was introduced in a bath at $08 \mathrm{C}, 4 \mathrm{a} \mathrm{MS}(110 \mathrm{mg})$ was then added followed by the corresponding imine $(0.125 \mathrm{mmol})$ dissolved in $\mathrm{dry}^{\mathrm{Et}} \mathrm{t}_{2} \mathrm{O}$ $(0.5 \mathrm{~mL})$ and by diisopropyl 2-isocyanatomalonate $(37 \mathrm{~mL}$, $0.19 \mathrm{mmol}$ ). The mixture was stirred at $08 \mathrm{C}$ for the indicated time and purified by column chromatography on silica gel eluting with hexane/EtOAc mixtures to give compounds 7. Compounds 5 and 6 were prepared following the same procedure by using diethyl or dimethyl 2-isocyanatomalonate, respectively.

\section{Acknowledgements}

Financial support (CTQ2013-47494-P) from the Ministerio de Economka y Competitividad (MINECO-Gobierno de EspaÇa) is gratefully acknowledged. M.E. thanks the Generalitat Valenciana for a predoctoral grant. Access to the NMR and MS facilities from the Servei Central de Suport a la Investigacij Experimental (SCSIE)-UV is also acknowledged.

\section{Conflict of interest}

The authors declare no conflict of interest.

Keywords: asymmetric catalysis - enantioselectivity · lactams nitrogen heterocycles $\cdot$ nucleophilic addition

[1] Reviews: a) S. Hanessian, L. Auzzas, Acc. Chem. Res. 2008, 41, $1241-$ 1251 ; b) C. N\#jera, M. Yus, Tetrahedron: Asymmetry 1999, 10, $2245-$ 2303 ; c) A. Stefanucci, E. Novellino, R. Costante, A. Mollica, Heterocycles 2014, 89, 1801-1825. Selected examples: d) C. Zanato, S. Watson, G. S. Bewick, W. T. A. Harrison, M. Zanda, Org. Biomol. Chem. 2014, 12, 9638 9643; e) S. V. Pansare, K. G. Kulkarni, RSC Adv. 2013, 3, 19127-19134; f) K. Yamada, T. Sato, M. Hosoi, Y. Yamamoto, K. Tomioka, Chem. Pharm. Bull. 2010, 58, 1511-1516; g) A. Hameed, A. J. Blake, C. J. Hayes, Synlett 2010, 535-538.

[2] P. Geoghegan, P. O'Leary, Tetrahedron: Asymmetry 2010, 21, 867-870.

[3] a) R. H. Feling, G. O. Buchanan, T. J. Mincer, C. A. Kauffman, P. R. Jensen, W. Fenical, Angew. Chem. Int. Ed. 2003, 42, 355-357; Angew. Chem. 2003, 115, 369-371; b) T. A. M. Gulder, B. S. Moore, Angew. Chem. Int. Ed. 2010, 49, 9346-9367; Angew. Chem. 2010, 122, 9534-9556.

[4] a) S. Omura, T. Fujimoto, K. Otoguro, K. Matsuzaki, R. Moriguchi, H. Tanaka, Y. Sasai, J. Antibiot. 1991, 44, 113-116; b) S. Omura, K. Matsuza- 
ki, T. Fujimoto, K. Kosuge, T. Furuya, S. Fujita, A. Nakagawa, J. Antibiot. 1991, 44, 117-118; c) G. Fenteany, S. L. Schreiber, J. Biol. Chem. 1998, 273, 8545-8548; d) R. R. Manam, V. R. Macherla, G. Tsueng, C. W. Dring, J. Weiss, S. T. C. Neuteboom, K. S. Lam, B. C. Potts, J. Nat. Prod. 2009, 72, $295-297$.

[5] a) T. Mori, K. Takahashi, M. Jashiwabara, D. Uemura, Tetrahedron Lett. 1985, 26, 1073-1076; b) M. G. Moloney, P. C. Trippier, M. Yaqoob, A. Wang, Curr. Drug Discovery Technol. 2004, 1, 181-199.

[6] a) R. Sakai, C. Oiwa, K. Takaishi, H. Kamiya, M. Tagawa, Tetrahedron Lett. 1999, 40, 6941-6944; b) R. Sakai, K. Suzuki, K. Shimamoto, H. Kamiya, J. Org. Chem. 2004, 69, 1180-1185.

[7] Y. Rombouts, E. Elass, C. Biot, E. Maes, B. Coddeville, A. Burguiere, C. Tokarski, E. Buisine, X. Trivelli, L. Kremer, Y. Guerardel, J. Am. Chem. Soc. 2010, 132, 16073-16084.

[8] a) Q. Yuan, D. Liu, W. Zhang, Org. Lett. 2017, 19, 1144-1147; b) V. Pace, J. P. Rae, D. J. Procter, Org. Lett. 2014, 16, 476-479; c) P. Moutevelis-Minakakis, E. Papavassilopoulou, T. Mavromoustakos, Molecules 2013, 18, 50-73; d) J.-F. Bai, L.-L. Wang, L. Peng, Y.-L. Guo, L.-N. Jia, F. Tian, G.-Y. He, X.-Y. Xu, L.-X. Wang, J. Org. Chem. 2012, 77, 2947-2953; e) M. J. Just, S. Tekkam, M. A. Alam, S. C. Jonnalagadda, J. L. Johnson, V. R. Mereddy, Tetrahedron Lett. 2011, 52, 5349-5351.

[9] a) B. G. Chatterjee, D. P. Sahu, J. Org. Chem. 1977, 42, 3162-3165; b) J. Yang, X. Zhou, Y. Zeng, C. Huang, Y. Xiao, J. Zhang, Chem. Commun. 2016, 52, 4922-4925; c) D. Deredas, L. Albrecht, H. Krawczyk, Tetrahedron Lett. 2013, 54, 3088-3090.

[10] M. Scansetti, X. Hu, B. P. McDermott, H. W. Lam, Org. Lett. 2007, 9, 2159-2162.

[11] a) K. Takahashi, M. Midori, K. Kawano, J. Ishihara, S. Hatakeyama, Angew. Chem. Int. Ed. 2008, 47, 6244-6246; Angew. Chem. 2008, 120, 63406342 ; b) H. A. Keane, W. Hess, J. W. Burton, Chem. Commun. 2012, 48, 6496-6498; c) W. Hess, J. W. Burton, Adv. Synth. Catal. 2011, 353, 29662970.

[12] a) C. H. Yoon, D. L. Flanigan, B.-D. Chong, K. W. Jung, J. Org. Chem. 2002, $67,6582-6584$; b) M. Oba, N. Nishiyama, K. Nishiyama, Chem. Commun. 2003, 776-777; c) V. A. Soloshonok, H. Ueki, R. Tiwari, J. Org. Chem. 2004, 69, 4984-4990; d) M. K. Ghorai, D. P. Tiwari, J. Org. Chem. 2010, $75,6173-6181$.

[13] a) M. S. Taylor, E. N. Jacobsen, J. Am. Chem. Soc. 2003, 125, $11204-$ 11205 ; b) S. Vellalath, K. N. Van, D. Romo, Angew. Chem. Int. Ed. 2013, 52, 13688-13693; Angew. Chem. 2013, 125, 13933-13938; c) L. Chen, Z.-J. Wu, M.-L. Zhang, D.-F. Yue, X.-M. Zhang, X.-Y. Xu, W.-C. Yuan, J. Org. Chem. 2015, 80, 12668-12675; d) Z.-Y. Xue, Z.-M. Song, C.-J. Wang, Org. Biomol. Chem. 2015, 13, 5460-5466.

[14] a) D. E. A. Raup, B. Cardinal-David, D. Holte, K. A. Scheidt, Nat. Chem. 2010, 2, 766-771; b) X. Zhao, D. A. DiRocco, T. Rovis, J. Am. Chem. Soc. 2011, 133, $12466-12469$.

[15] X. Companyj, P.-Y. Geant, A. Mazzanti, A. Moyano, R. Rios, Tetrahedron 2014, 70, 75-82.

[16] Selected examples with aldehydes and ketones: a) Y. Ito, M. Sawamura, T. Hayashi, J. Am. Chem. Soc. 1986, 108, 6405-6406; b) A. Togni, S. D. Pastor, J. Org. Chem. 1990, 55, 1649-1664; c) M. Sawamura, Y. Nakayama, T. Kato, Y. Ito, J. Org. Chem. 1995, 60, 1727-1732; d) M. Sawamura, H. Hamashima, Y. Ito, J. Org. Chem. 1990, 55, 5935-5936; e) S. Gosiewska, M. F. I. Veld, J. J. M. de Pater, P. C. A. Bruijnincx, M. Lutz, A. L. Spek, G. van Koten, R. J. M. Klein Gebbink, Tetrahedron: Asymmetry 2006, 17, 674-686; f) N. Lin, Y.-Q. Deng, Z.-W. Zhang, Q. Wang, G. Lu, Tetrahedron: Asymmetry 2014, 25, 650-657; g) F. Sladojevich, A. Trabocchi, A. Guarna, D. J. Dixon, J. Am. Chem. Soc. 2011, 133, 1710-1713; h) R. de la Campa, I. Ortan, D. J. Dixon, Angew. Chem. Int. Ed. 2015, 54, 4895-4898; Angew. Chem. 2015, 127, 4977-4980; Selected examples with imines: i) X.-T. Zhou, Y.-R. Lin, L.-X. Dai, J. Sun, L.-J. Xia, M.-H. Tang, J. Org. Chem. 1999, 64, 1331-1334; j) Z.-W. Zhang, G. Lu, M.-M. Chen, N. Lin, Y.-B. Li, T. Hayashi, A. S. C. Chan, Tetrahedron: Asymmetry 2010, 21, 1715-1721; k) S. Nakamura, Y. Maeno, M. Ohara, A. Yamamura, Y. Funahashi, N. Shibata, Org. Lett. 2012, 14, 2960-2963; I) I. Ortłn, D. J. Dixon, Angew. Chem. Int. Ed. 2014, 53, 3462-3465; Angew. Chem. 2014, 126, $3530-$ 3533 ; m) P.-L. Shao, J.-Y. Liao, Y. A. Ho, Y. Zhao, Angew. Chem. Int. Ed. 2014, 53, 5435-5439; Angew. Chem. 2014, 126, 5539-5543; n) M. Hayashi, M. Iwanaga, N. Shiomi, D. Nakane, H. Masuda, S. Nakamura, Angew. Chem. Int. Ed. 2014, 53, 8411-8415; Angew. Chem. 2014, 126, 8551-
8555; 0) M.-X. Zhao, L. Jing, H. Zhou, M. Shi, RSC Adv. 2015, 5, 75648 75652 ; p) S. Nakamura, R. Yamaji, M. Iwanaga, Chem. Commun. 2016 , 52, 7462-7465; q) R. de la Campa, A. D. Gammack Yamagata, I. Ortin, A. Franchino, A. L. Thompson, B. Odell, D. J. Dixon, Chem. Commun. 2016, 52, $10632-10635$.

[17] Selected examples with aldehydes and ketones: a) M. C. Willis, G. A. Cutting, V. J.-D. Piccio, M. J. Durbin, M. P. John, Angew. Chem. Int. Ed. 2005, 44, 1543-1545; Angew. Chem. 2005, 117, 1567-1569; b) L. Li, E. G. Klauber, D. Seidel, J. Am. Chem. Soc. 2008, 130, 12248-12249; c) T. Yoshino, H. Morimoto, G. Lu, S. Matsunaga, M. Shibasaki, J. Am. Chem. Soc. 2009, 131, 17082-17083; d) X. Jiang, Y. Cao, Y. Wang, L. Liu, F. Shen, R. Wang, J. Am. Chem. Soc. 2010, 132, 15328-15333; e) X. Chen, Y. Zhu, Z. Qiao, M. Xie, L. Lin, X. Liu, X. Feng, Chem. Eur. J. 2010, 16, 1012410129; f) Y.-M. Cao, F.-F. Shen, F.-T. Zhang, J.-L. Zhang, R. Wang, Angew. Chem. Int. Ed. 2014, 53, 1862-1866; Angew. Chem. 2014, 126, $1893-$ 1897; Selected examples with imines: g) L. Li, M. Ganesh, D. Seidel, J. Am. Chem. Soc. 2009, 131, 11648-11649; h) X. Chen, S. Dong, Z. Qiao, Y. Zhu, M. Xie, L. Lin, X. Liu, X. Feng, Chem. Eur. J. 2011, 17, 2583-2586; i) G. Lu, T. Yoshino, H. Morimoto, S. Matsunaga, M. Shibasaki, Angew. Chem. Int. Ed. 2011, 50, 4382-4385; Angew. Chem. 2011, 123, 44744477; j) S. Kato, T. Yoshino, M. Shibasaki, M. Kanai, S. Matsunaga, Angew. Chem. Int. Ed. 2012, 51, 7007-7010; Angew. Chem. 2012, 124, 71137116; k) D. Du, Q. Xu, X.-G. Li, M. Shi, Chem. Eur. J. 2016, 22, 4733-4737.

[18] a) W.-T. Wei, C.-X. Chen, R.-J. Lu, J.-J. Wang, X.-J. Zhang, M. Yan, Org. Biomol. Chem. 2012, 10, 5245; b) L.-L. Wang, J.-F. Bai, L. Peng, L.-W. Qi, L.-N. Jia, Y.-L. Guo, X.-Y. Luo, X.-Y. Xu, L.-X. Wang, Chem. Commun. 2012 , 48, 5175; c) J.-Y. Liao, P.-L. Shao, Y. Zhao, J. Am. Chem. Soc. 2015, 137, 628 ; d) X.-J. Peng, Y. A. Ho, A.-P. Wang, P.-L. Shao, Y. Zhao, Y. He, Org. Chem. Front. 2017, 4, 81.

[19] a) Y. Cao, X. Jiang, L. Liu, F. Shen, F. Zhang, R. Wang, Angew. Chem. Int. Ed. 2011, 50, 9124-9127; Angew. Chem. 2011, 123, 9290-9293; b) B. Tan, X-Zeng, W. W. Y. Leong, Z. Shi, C. F. Barbas, G. Zhong, Chem. Eur. J. 2012, 18, 63-67; c) H. Wu, L.-L. Zhang, Z.-Q. Tian, Y.-D. Huang, Y.-M. Wang, Chem. Eur. J. 2013, 19, 1747-1753; d) Q. Chen, J. Liang, S. Wang, D. Wang, R. Wang, Chem. Commun. 2013, 49, 1657-1659; e) D. Du, Y. Jiang, Q. Xu, X.-Y. Tang, M. Shi, ChemCatChem 2015, 7, 1366-1371; f) H.W. Zhao, T. Tian, H.-L. Pang, B. Li, X.-Q. Chen, Z. Yang, W. Meng, X.-Q. Song, Y.-D. Zhao, Y.-Y. Liu, Adv. Synth. Catal. 2016, 358, 2619-2630; g) R. Chowdhury, M. Kumar, S. K. Ghosh, Org. Biomol. Chem. 2016, 14, 1125011260.

[20] a) L. Šenica, K. Stopar, M. Friedrich, U. Grošelj, J. Plavec, M. Počkaj, C. Podlipnik, B. Štefane, J. Svete, J. Org. Chem. 2016, 81, 146-161; b) E. R. Shore, M. Awais, N. M. Kershaw, R. R. Gibson, S. Pandalaneni, D. Latawiec, L. Wen, M. A. Javed, D. N. Criddle, N. Berry, P. M. O'Neill, L.-Y. Lian, R. S. Sutton, J. Med. Chem. 2016, 59, 2596-2611; c) G. Singh, J. Aube, Org. Biomol. Chem. 2016, 14, 4299-4303.

[21] S. Sakamoto, N. Kazumi, Y. Kobayashi, C. Tsukano, Y. Takemoto, Org. Lett. $2014,16,4758-4761$.

[22] A related reaction involving the addition of bis(silyl)methylisocyanates to aldehydes and imines has been reported: G. Barbaro, A. Battaglia, P. Giorgianni, A. Guerrini, G. Seconi, J. Org. Chem. 1995, 60, 6032-6039.

[23] a) M. Espinosa, G. Blay, L. Cardona, J. R. Pedro, Chem. Eur. J. 2013, 19, 14861-14866; b) M. Espinosa, G. Blay, L. Cardona, J. R. Pedro, Chem. Eur. J. 2013, 19, 17632-17632; c) M. Espinosa, A. Garcia-Ortiz, G. Blay, L. Cardona, M. C. MuÇoz, J. R. Pedro, RSC Adv. 2016, 6, 15655-15659.

[24] Preliminary experiments on the reaction of diethyl 2-isocyanatomalonate with chalcone or its $\mathrm{N}$-tosyl imine derivate showed that these were not reactive in the presence of $\mathrm{Mg}$-BOX complexes.

[25] Imines 4 have an $E$ geometry at the $\mathrm{C}=\mathrm{C}$ bond, but were prepared and used as $2: 1$ to $7: 3$ mixtures of $\mathrm{C}=\mathrm{N}$ geometric isomers.

[26] See the Supporting Information for further details. CCDC 1544707 (7b) and 1544708 (9a) contain the supplementary crystallographic data for this paper. These data can be obtained free of charge from The Cambridge Crystallographic Data Centre.

Manuscript received: June 16, 2017

Accepted manuscript online: August 28, 2017

Version of record online: September 21, 2017 